\title{
IODP Expeditions 309 and 312 Drill an Intact Section of Upper Oceanic Basement into Gabbros
}

\author{
by Jeffrey C. Alt, Damon A.H. Teagle, Susumu Umino, Sumio Miyashita, Neil R. Banerjee, \\ Douglas S. Wilson, the IODP Expeditions 309 and 312 Scientists, \\ and the ODP Leg 206 Scientific Party
} doi:10.2204/iodp.sd.4.01.2007

\section{Summary}

The Integrated Ocean Drilling Program's (IODP) Expeditions 309 and 312 successfully completed the first sampling of an intact section of upper oceanic crust, through lavas and the sheeted dikes into the uppermost gabbros. Hole 1256D, which was initiated on the Ocean Drilling Program's (ODP) Leg 206, now penetrates to $>1500 \mathrm{mbsf}$ and $>1250 \mathrm{~m}$ sub-basement. The first gabbroic rocks were encountered at 1407 mbsf. Below this, the hole penetrates $\sim 100 \mathrm{~m}$ into a complex zone of fractionated gabbros intruded into contact metamorphosed dikes.

\section{Deep Drilling of the Ocean Basement}

Drilling a complete in situ section of ocean crust has been an unfulfilled ambition of Earth scientists since the inception of ocean drilling that followed the audaciously ambitious Project MoHole, which was targeted to sample the first order seismic boundary named the Mohorovičić discontinuity ('Moho'; see Bascom, 1961; Greenberg, 1974). The principal emphasis of Project MoHole was to understand the nature of the oceanic crust and the underlying uppermost mantle thought to be separated by the Moho at roughly $6 \mathrm{~km}$ depth below the ocean basins. Unfortunately, many of the key questions regarding the formation and evolution of the oceanic crust remain unanswered despite a further forty years of research; moreover, our sampling of the ocean crust remains extremely cursory (see compilations in Teagle et al., 2004; Wilson et al., 2003). Although offset drilling strategies, where deeper parts of the ocean crust are sampled by drilling in tectonic windows, have had notable success (e.g., Hess Deep, ODP Leg 147; Southwest Indian Ridge, ODP Leg 176; Mid-Atlantic Ridge, Ildefonse et al., 2006), composite sections of the ocean crust are not substitutes for long continuous drill holes into intact crust far from fracture zones. Before the recent success of drilling at Site 1256, only Hole 504B, located in 6.9-Ma old crust on the southern flank of the intermediate spreading rate Costa Rica Rift, had sampled through the lava-dike transition (Alt et al., 1996). However, the sheeted dike-gabbro transition had never been drilled, even though it is critical to deciphering crustal accretion processes at midocean ridges.

The IODP Expeditions 309 and 312 therefore tackled a major unfulfilled goal of ocean drilling-namely the sampling of a complete section from lavas, through the dikes, and into gabbros. This was accomplished by drilling Hole 1256D in crust that formed at a superfast spreading rate at the East Pacific Rise 15 -My ago (Fig. 1). This approach exploits the apparent inverse relationship between the depth of axial low velocity zones, hypothesized to be magma chambers, and spreading rate (Fig. 2). Drilling took place on three scientific ocean drilling cruises: ODP Leg 206 (Wilson et al., 2003) and IODP Expeditions 309 and 312 (IODP Expedition 309 Scientists, 2005; IODP Expedition 309/312 Scientists, 2006; Teagle et al., 2006; Wilson et al., 2006). IODP Expedition 312 was the last cruise of IODP Phase I and the final scientific drilling voyage of JOIDES Resolution before major refitting and renaming. The successful accomplishment of the

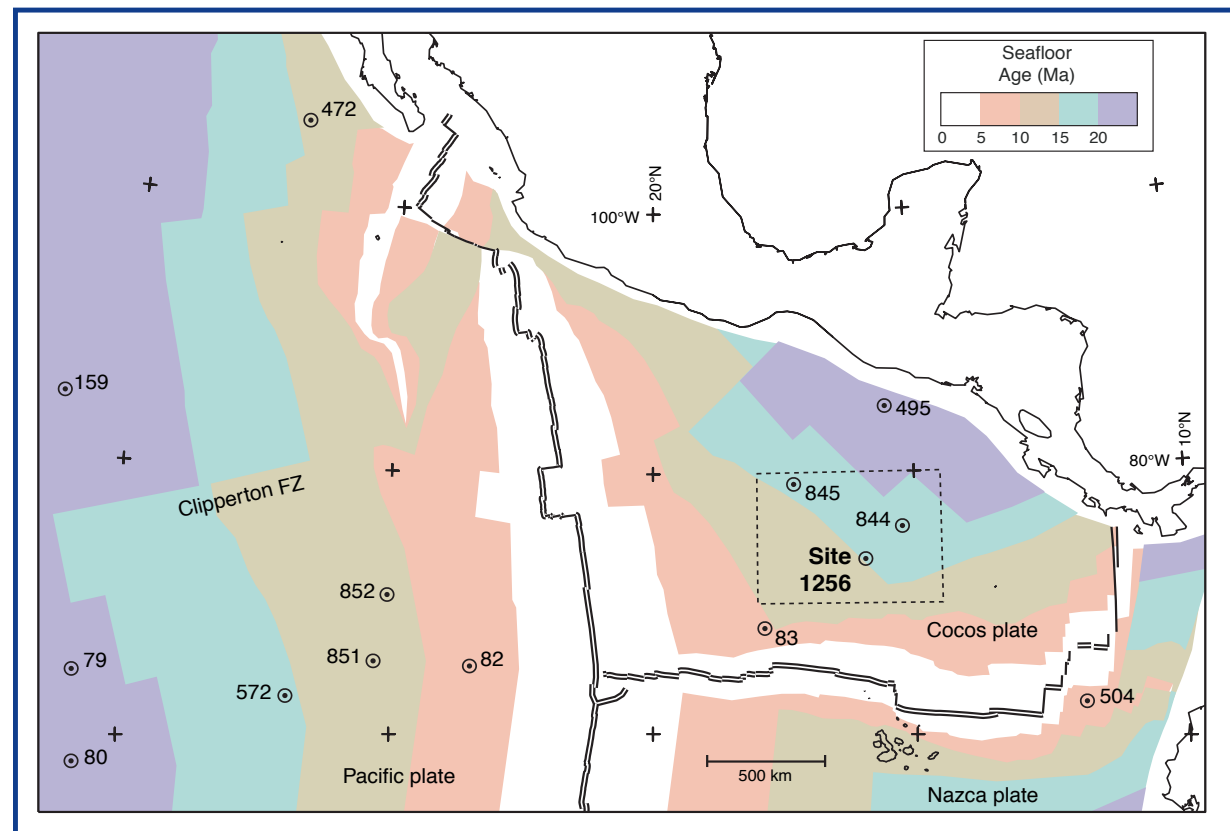

Figure 1. Age map of the Cocos plate and East Pacific Rise with isochrons at 5-My intervals, converted from magnetic anomaly identifications according to timescale of Cande and Kent (1995). The wide spacing of 10-20 Ma isochrons to the south reflects the extremely fast (200-220 $\mathrm{mm} \mathrm{yr}^{-1}$ ) full spreading rate. The locations of deep drill holes into the oceanic crust at Sites 1256 and 504 are shown. 
longstanding scientific ocean drilling ambition of coring to gabbros in situ is a fitting finale to the JOIDES Resolution's achievements and to Phase I of IODP.

\section{Goals of IODP Expeditions 309 and 312}

Deep basement drilling at Site 1256 had four principal scientific objectives:

1. Test the prediction that gabbros representing the crystallized melt lens should be encountered at a depth of 900-1300 m subbasement at Site 1256 from the correlation of spreading rate with decreasing depth to the axial melt lens

2. Determine the lithology and structure of the upper oceanic crust for the superfast spreading end-member

3. Correlate and calibrate remote geophysical seismic and magnetic imaging of the structure of the crust with basic geological observations

4. Investigate the interactions between magmatic and alteration processes, including the relationships between extrusive volcanic rocks, the feeder sheeted dikes, and the underlying gabbroic rocks.

\section{Highlights of Deep Drilling in Hole 1256D}

ODP Leg 206 installed a reentry cone supported by 20 -inch casing with a large-diameter (16-inch) casing that sealed off the $250-\mathrm{m}$ sediment blanket and cemented $19 \mathrm{~m}$ into the basement. Using the large-diameter casing left open the possibility that additional casing strings could be installed if future expeditions decided to isolate eroded portions of the hole. Leg 206 then deepened the hole through $502 \mathrm{~m}$ of massive lavas and sheet flows with moderate to high recovery (48\%; Wilson et al., 2003). IODP Expeditions 309 and 312 deepened Hole 1256D by $755.1 \mathrm{~m}$ to $1507.1 \mathrm{mbsf}$ (Fig. 3). The uppermost basement comprises a $\sim 100$-m-thick sequence of lava dominated by a single flow up to $75 \mathrm{~m}$ thick, requiring at least that much seafloor relief to pool the lava. On modern fast spreading ridges, such topography does not normally develop until $5-10 \mathrm{~km}$ from the axis. The lavas immediately below include sheet and massive flows and minor pillow flows. Sub-vertical, elongate, flow-top fractures filled with quenched glass and hyaloclastite in these lavas indicate flow lobe inflation requiring eruption onto a sub-horizontal surface off-axis (Umino et al., 2000). Thus, we estimate a total thickness of $284 \mathrm{~m}$ for off-axis lavas, close to the assumed thickness. Sheet flows and massive lavas that erupted at the ridge axis make up the remaining extrusive section down to $1004 \mathrm{mbsf}$, before a lithologic transition is marked by sub-vertical intrusive contacts and mineralized breccias. Below $1061 \mathrm{mbsf}$, subvertical intrusive contacts are numerous, indicating the start of a relatively thin ( 350-m-thick) sheeted dike complex that is dominated by massive basalts. Some basalts have doleritic textures, and many are cut by sub-vertical dikes with common strongly brecciated and mineralized chilled margins. There is no

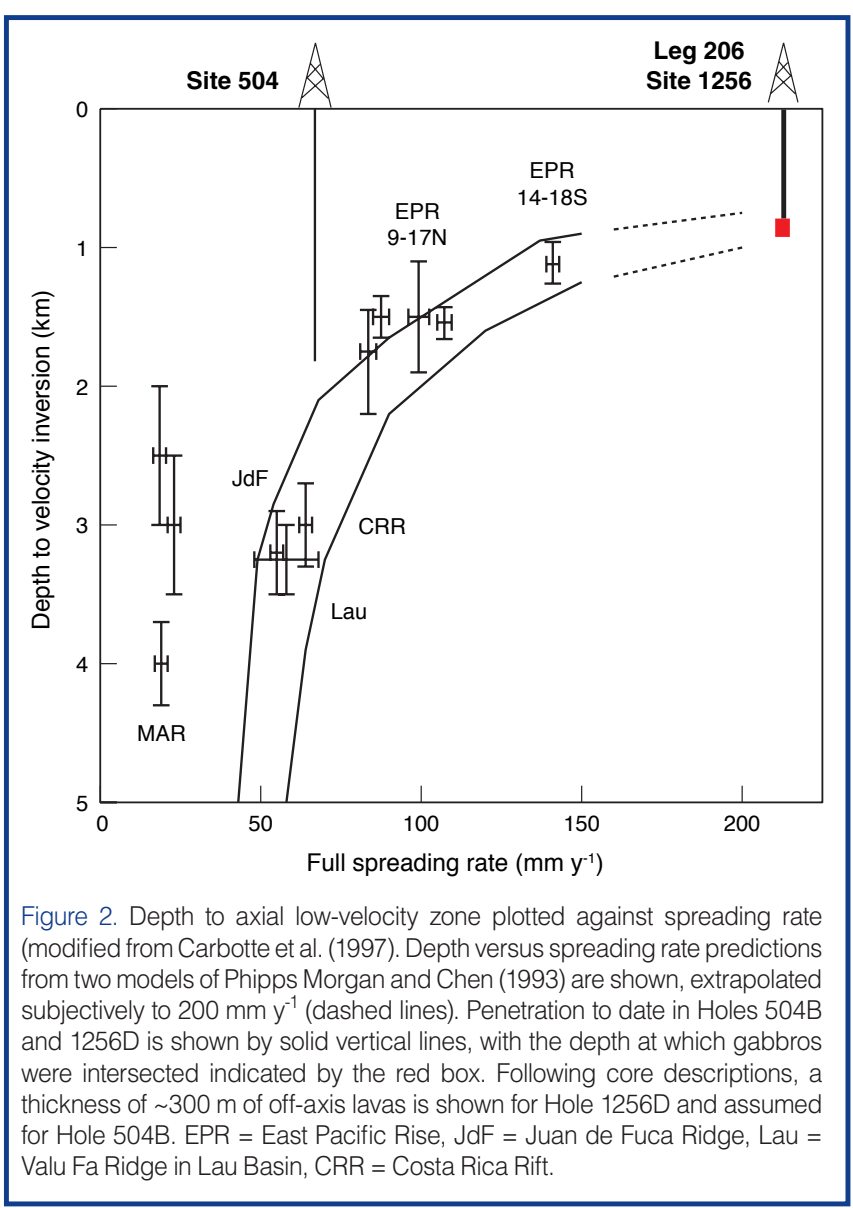

evidence from core or from geophysical wireline logs for significant tilting of the dikes. This is consistent with seismic reflection images of sub-horizontal reflectors in the lower extrusive rocks that are continuous for several kilometers across the site (Hallenborg et al., 2003).

There is a stepwise increase in alteration grade downward from lavas into dikes, with low temperature phases $\left(<150^{\circ} \mathrm{C}\right.$; phyllosilicates, iron oxyhydroxides) in the lavas giving way to dikes partially altered to chlorite and other greenschist minerals (at temperatures greater than $\sim 250^{\circ} \mathrm{C}$; Fig. 3). Within the dikes the alteration intensity and grade increase downward, with actinolite more abundant than chlorite below $1300 \mathrm{mbsf}$ and with hornblende present below $1350 \mathrm{mbsf}$. These results indicate temperatures approaching $\sim 400^{\circ} \mathrm{C}$. The dikes have significantly lower porosity (mostly $0.5 \%-2 \%$ ) and higher $\mathrm{P}$-wave velocities and thermal conductivity than the lavas, and porosity decreases while P-wave velocity increases with depth in the dikes. In the lower $\sim 60 \mathrm{~m}$ of the sheeted dikes (1348 to $1407 \mathrm{mbsf}$ ), basalts are partially to completely recrystallized to distinctive granoblastic textures resulting from contact metamorphism by underlying gabbroic intrusions (Fig. 4).

Gabbro and trondhjemite dikes intrude into sheeted dikes at 1407 mbsf, marking the top of the plutonic complex. Two major bodies of gabbro were penetrated beneath this contact, with the 52-m-thick upper gabbro separated from the 24 -m-thick lower gabbro by a $24-\mathrm{m}$ screen of granoblastic 
dikes (Fig. 4). The upper gabbro comprises gabbros, oxide gabbros, quartz-rich oxide diorites and small trondhjemite dikelets. These rocks are moderately to highly altered by hydrothermal fluids to actinolitic hornblende, secondary plagioclase, epidote, chlorite, prehnite, and laumontite. The intensity of hydrothermal alteration increases with grain size and proximity to intrusive boundaries.

The lower gabbro comprises gabbro, oxide gabbro, and subordinate orthopyroxene-bearing gabbro and trondhjemite that are similarly altered. It also has clear intrusive contacts with the overlying granoblastic dike screen. Partially

resorbed, stoped dike clasts are entrained within both the upper and lower margins of the lower gabbro (Fig. 4G). The lowermost rock recovered from Hole $1256 \mathrm{D}$ is a highly altered actinolite-bearing basaltic dike that lacks granoblastic textures, and is therefore interpreted to be a late dike that post-dates the intrusion of the lower gabbro.

Contrary to expectation, porosity increases and P-wave velocities decrease stepwise downward from lowermost dikes into the uppermost gabbro at Hole $1256 \mathrm{D}$, as a result of the contact metamorphism of the granoblastic dikes and the strong hydrothermal alteration of the uppermost gabbros (Fig. 3). Porosity and velocity then increase downhole in the gabbro but are still $<6.5 \mathrm{~km} \mathrm{~s}^{-1}$.

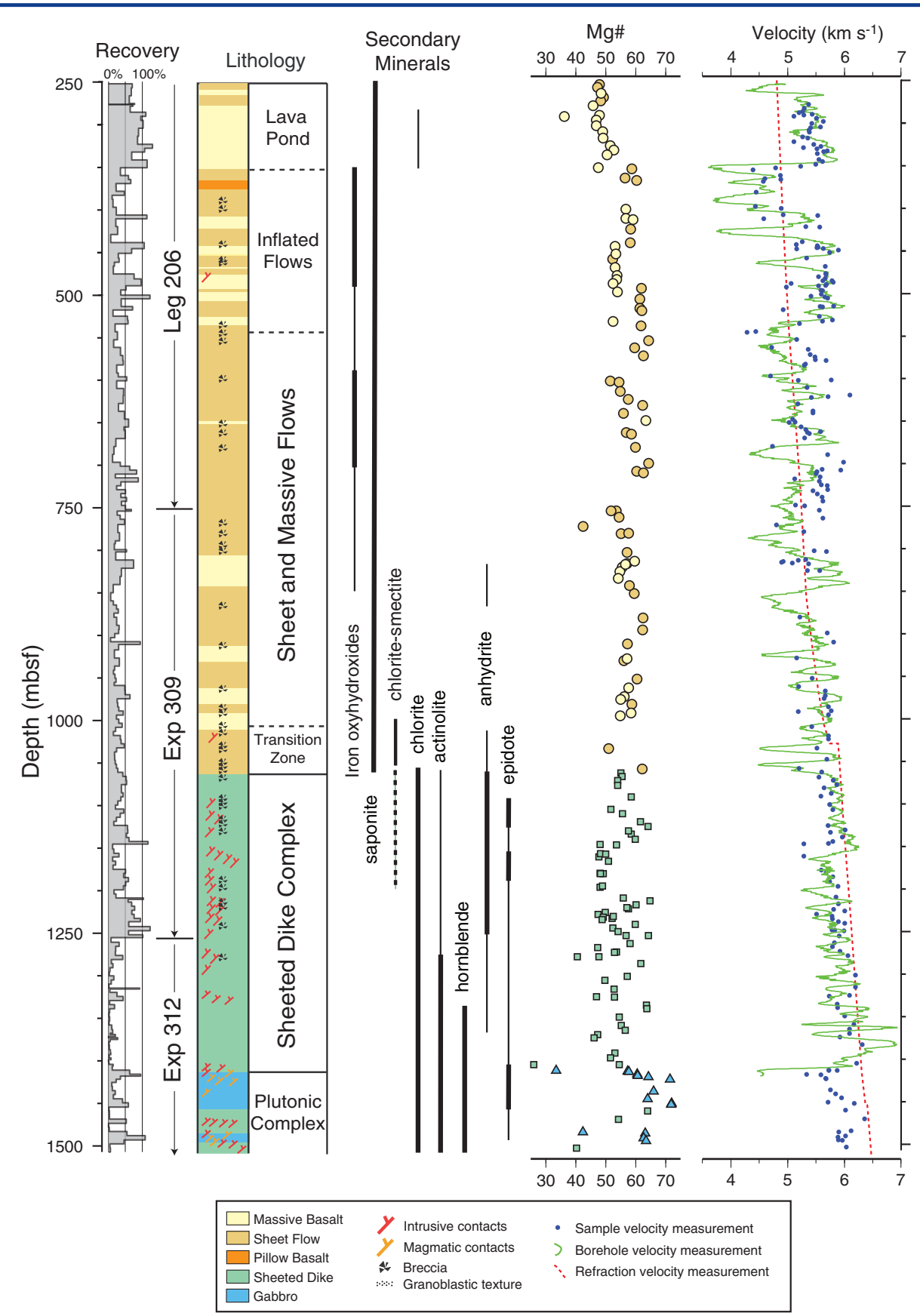

Figure 3. Summary lithostratigraphic column of the basement drilled to date at Site 1256 showing recovery, major lithologies, downcore index alteration, mineral distribution (thick lines = abundant; thin lines = rare), downcore distribution of $\mathrm{Mg}$-number (where $\mathrm{Mg} \#=100^{\circ}-\mathrm{Mg} /(\mathrm{Mg}+(0.9 \times \mathrm{Fe}))$ atomic ratio), and seismic velocity measured on discrete samples, wireline tools, and seismic refraction (from Wilson et al., 2006).
Flows and dikes from Hole $1256 \mathrm{D}$ show a wide range of magmatic fractionation, from fairly primitive to evolved (Figs. 3 and 5). Shallower than $600 \mathrm{mbsf}$, magma compositions are bimodal, with relatively evolved thick flows and more primitive thin flows. Primitive and evolved compositions are closely juxtaposed within the dikes, as would be expected for vertically intruded magmas. For most major elements and many trace elements, the range of concentrations in flows and dikes is similar to that observed for the northern East Pacific Rise (EPR, e.g., Fig. 5). A few incompatible elements, including $\mathrm{Na}$ and $\mathrm{Zr}$, have lower concentrations than observed for the modern EPR lavas, but the general overlap of compositions indicates similar processes at the superfast spreading ridge that formed Site 1256 and the modern EPR. The gabbro compositions span a range similar to the flows and dikes, but are on average more primitive. Even though less fractionated, the average gabbro composition is evolved relative to candidates for primary magma in equilibrium with mantle olivine. Therefore, the residue removed from primary magma to produce the observed gabbro and basalt compositions must be deeper than the uppermostgabbrospenetrated in Hole $1256 \mathrm{D}$. 


\section{Conclusions from Site 1256}

The ocean crust is subdivided into three seismiclayers: layer one comprises sediments and has low velocity; layer two has low velocity and a high velocity gradient; layer three is characterized by high velocity (at least $6.7 \mathrm{~km} \mathrm{~s}^{-1}$ ) and low gradient. There is a widespread perception that layer three is equivalent to gabbro, even though Hole 504B has penetrated that layer but not gabbro (Alt et al., 1996). Seismic velocities of discrete shipboard samples and from wireline tools indicate velocities for gabbro in Hole $1256 \mathrm{D}$ are $<6.5 \mathrm{~km} \mathrm{~s}^{-1}$ and do not fit models for layer three. Further drilling in Hole 1256D, however, could recover samples to characterize the transition between seismic layers.

Site 1256 has a relatively thick lava sequence and a thin dike sequence. The thick lava sequence with many massive flows is interpreted as a consequence of short vertical transport distance from the shallow magma chamber. There is little evidence for tilting (at most a few degrees) in Hole 1256D and no evidence for significant faulting. The ponded flow at Site 1256, however, indicates that faults of $\sim 50-100 \mathrm{~m}$ offset must exist in superfast crust to provide the necessary relief for ponding of the flow.

When intruded as a magma, the upper gabbro in Hole 1256D would likely have had depth and impedance properties consistent with the geophysically imaged melt lenses at mid-ocean ridges. However, this gabbro body is chilled against the underlying dike screen, which precludes segregating a crystal residue that subsides to form the lower crust as in the gabbro glacier model. Thus, sills or other bodies containing cumulate materials must exist deeper in the crust or underlying mantle, but could be as shallow as just below the present maximum depth of Hole 1256D.

The $~ 800$-m-thick lava sequence is generally less hydrothermally altered than other basement sites (Wilson et al., 2003), and the distributions of secondary

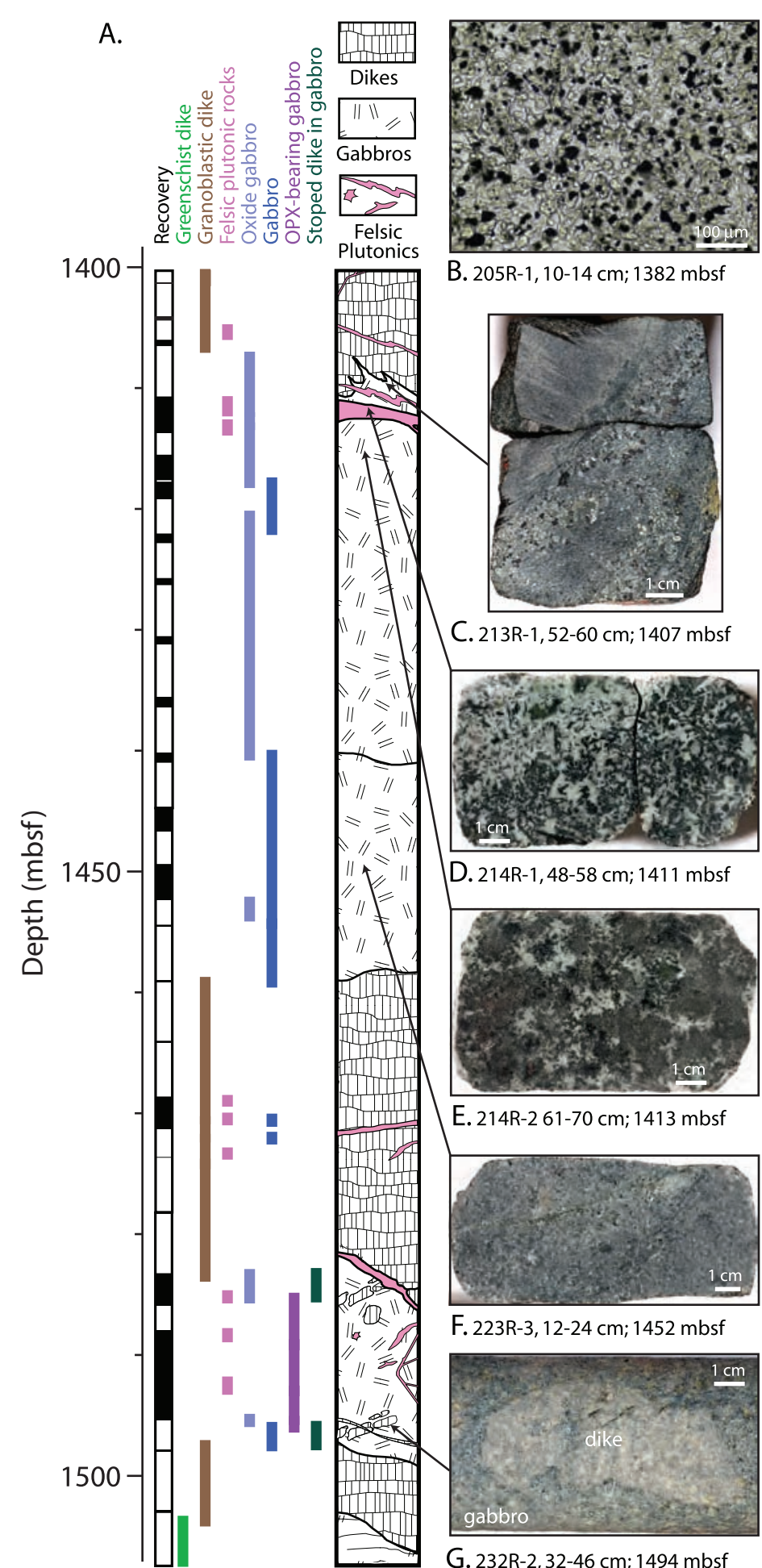

Figure 4. [A] Schematic lithostratigraphic section of the plutonic complex from the lower portion of Hole $1256 \mathrm{D}$ with representative photographs of key samples. The distribution of rock types is expanded proportionately in zones of incomplete recovery. Felsic plutonic rocks include quartz-rich oxide diorite and trondjhemite. [B] Photomicrograph of a dike completely recrystallized to a granoblastic association of equant secondary plagioclase, clinopyroxene, magnetite, and ilmenite. Some granoblastic dikes have minor orthopyroxene. [C] The dike-gabbro boundary! Medium-grained oxide gabbro is intruded into granoblastically recrystallized dike along an irregular moderately dipping contact. The gabbro is strongly hydrothermally altered. [D] Quartz-rich oxide diorite strongly altered to actinolitic hornblende, secondary plagioclase, epidote, and chlorite. Epidote occurs in 5-mm clots in the finer grained leucocratic portions of the rock. [E] Disseminated oxide gabbro with patchy texture and $\mathrm{cm}$-scale dark ophitically intergrown clinopyroxene and plagioclase patches separated by irregular, more highly altered leucocratic zones. [F] Medium-grained strongly hydrothermally altered gabbro. The sample is cut by several chlorite and actinolite veins with light gray halos. Plagioclase is replaced by secondary plagioclase and clinopyroxene by amphibole. [G] Clast of partially resorbed dike within gabbro. (photos from Wilson et al.). 


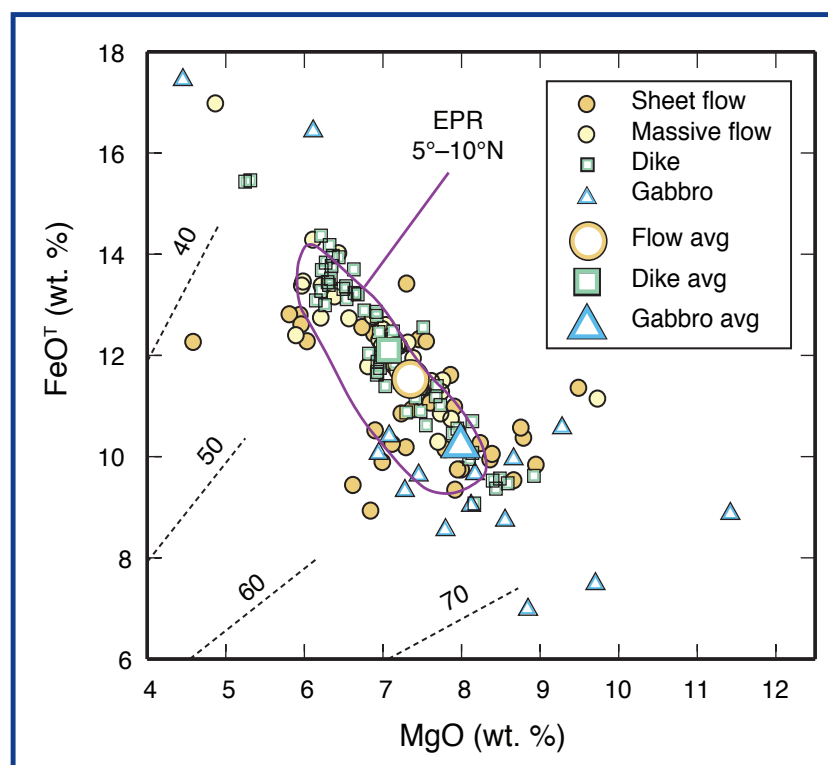

Figure 5. FeO' (Total Fe expressed as FeO) vs. MgO for the basement at Site 1256, compared with analyses of northern EPR. Dashed lines show constant Mg number. Possible primary mantle melt compositions should have $\mathrm{Mg}$ number of $70-78$ and $\mathrm{MgO}$ of $9-14 \mathrm{wt}$. \%. All flows and dikes and most gabbros are too evolved to be candidates for primary magmas (from Wilson et al., 2006).

minerals indicate a structural control of alteration rather than simply decreasing seawater influence downward. There is a stepwise increase in alteration temperatures downhole, from $\sim 100^{\circ} \mathrm{C}$ in the lavas to $\sim 250^{\circ} \mathrm{C}$ in the uppermost dikes. Aside from the granoblastic contact metamorphic assemblages in the basal dikes, hydrothermal mineralogy and inferred alteration temperatures of the lower dikes in Hole $1256 \mathrm{D}$ are generally similar to those in the lower dikes of Hole 504B (up to $\sim 400^{\circ} \mathrm{C}$ ). The much thinner dike section at Site 1256 than at Site 504 ( 350 vs. $\sim 1000 \mathrm{~m})$, however, indicates a much steeper hydrothermal temperature gradient at Site 1256 $\left(\sim 0.5^{\circ} \mathrm{C} \mathrm{m}^{-1}\right.$ vs. $0.16^{\circ} \mathrm{C} \mathrm{m}^{-1}$ in $\left.504 \mathrm{~B}\right)$.

Epidosites (equigranular epidote-quartztitanite rocks) delineate zones of upwelling black smoker-type fluids around the dikegabbro boundary in ophiolites. Although epidote is common within and below the transition zone in Hole 1256D (Fig. 3), epidosites were not encountered. Anhydrite precipitation must play a critical, but so far poorly understood, role in oceanic hydrothermal circulation. Anhydrite in Hole 1256D (Fig. 3) is more abundant than in Hole 504B, but it is still present in much lower quantities than predicted by models of hydrothermal circulation.

\section{Technical Challenges}

Even coring basement to more typical depths of a few hundred meters can run into technical problems, so coring to more than $1 \mathrm{~km}$ subbasement and through particularly hard dike formations presented challenges. Figure 6 shows drilling progress versus time at Site 1256 . The first challenge (the flat portion of the depth vs. time line at the top of Hole 1256D in Fig. 6) was the installation of the large-diameter (20-inch) casing through sediment, then the drilling out of a 21 -inch hole in basement below the 20 -inch casing in order to accept the 16 -inch basement casing. This required the use of a bi-center reamer, which has an 18-inch pass-through diameter that allows this hardware to fit through the 20 -inch casing. During drilling, the actual diameter of the cut hole is 21 inches. This was the first time such a device was used in scientific ocean drilling.

At 900 mbsf during Leg 309 (Fig. 6), the driller noted a loss of pump pressure, so the drill string was pulled. A horizontal gash was discovered that had nearly severed the bit sub (Fig. 7). A second torsional failure of the drill string occurred in the 5 -inch pipe above the bit sub. Such a failure of the bit sub-assembly had not been witnessed before in the shipboard memory of scientific ocean drilling, and the rapid diagnosis and response of the Transocean operations team certainly averted a costly and time-consuming major equipment loss in Hole 1256D.

Coring in the very hard recrystallized lower dikes proceeded slowly, and at 1372.8 mbsf with generally good drilling conditions, the fifth coring bit of IODP Expedition 312 failed (Figs. 6 and cover picture). Cleaning out the metal debris from the bottom of the hole required four fishing round trips (two with a fishing magnet and two with a mill) before coring could be confidently resumed. Despite these

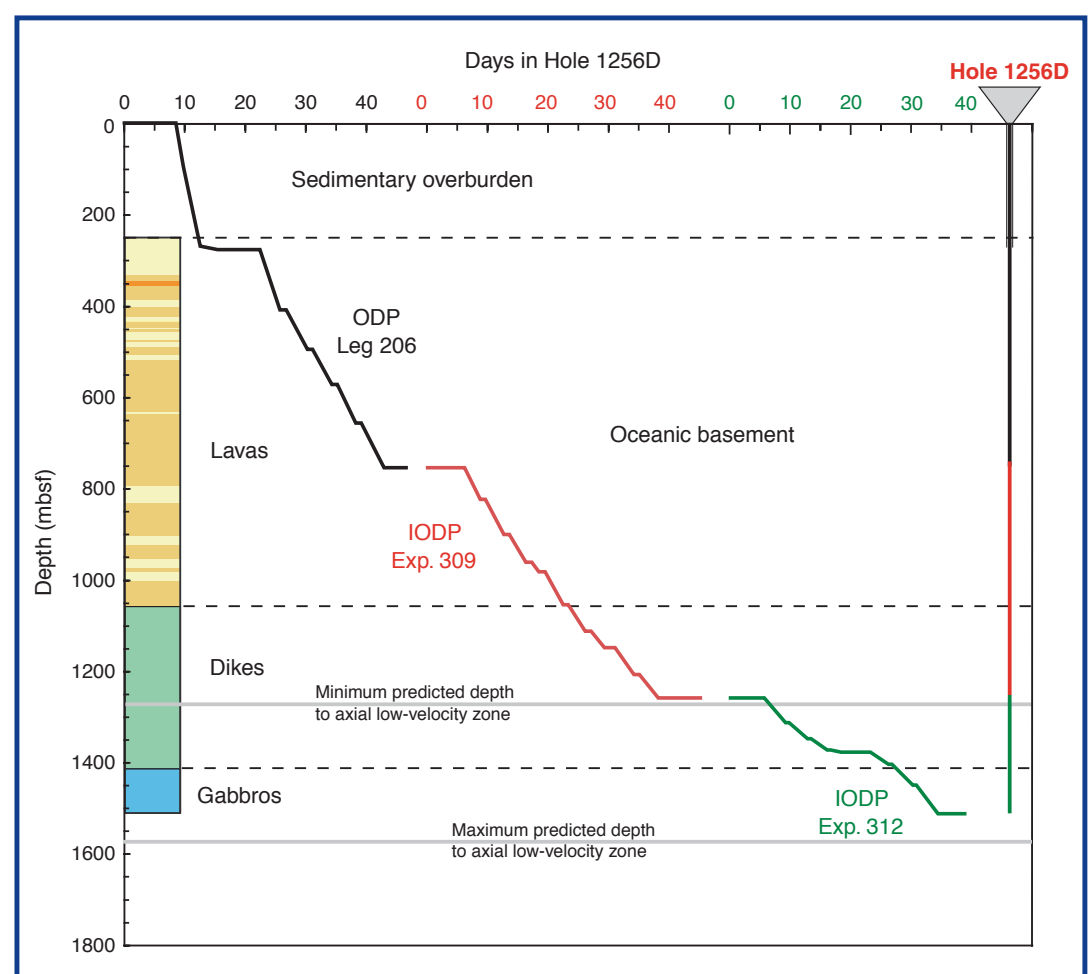

Figure 6. Drilling progress versus time in Hole 1256D. 
technical challenges, the major operational goal of the expeditions, coring into gabbro, was successfully achieved.

\section{Goals of Future Drilling at Site 1256}

Although the major objective of penetrating into gabbro was achieved, critical scientific questions remain to be answered. These include the following: 1) Does the lower crust form by the recrystallization and subsidence of a high level magma chamber ("gabbro glacier"), or by crustal accretion from intrusion of sills throughout the lower crust? 2) Is the plutonic crust cooled by conduction or hydrothermal circulation? 3) What is the geological nature of layer three and the layer two/three boundary at Site 1256? 4) What is the magnetic contribution of the lower crust to marine magnetic anomalies? Hole $1256 \mathrm{D}$ is poised at a depth where samples that would conclusively address these questions could be obtained, possibly with only a few hundred more meters of drilling. What is important is that the hole is clear of debris and open to its full depth. Increased rates of penetration $\left(1.2 \mathrm{~m} \mathrm{~h}^{-1}\right)$ and core recovery $(>35 \%)$ in the gabbros indicate that a return to Hole $1256 \mathrm{D}$ could deepen the hole at least a further $500 \mathrm{~m}$ into plutonic rocks, past the present transition from dikes to gabbro, and into a region of solely gabbroic rocks.

\section{The IODP Expedition 309 and 312 Scientists and ODP Leg 206 Scientific Party}

J.C. Alt b,f, D.A.H. Teagle a,d,h , S. Umino ${ }^{\text {d,f }}$, S. Miyashita ${ }^{b}$, N.R. Banerjee c,f, D.S. Wilson a,g,h, G.D. Acton e, R. Anma h, S.R. Barr ${ }^{\text {f }}$ A. Belghoul ${ }^{\text {g }}$, J. Carlut h, D.M. Christie ${ }^{\text {h }}$, R.M. Coggon f,h, K.M. Cooper f,C. Cordier ${ }^{\text {g }}$, L. Crispini f,g, S.R. Durand ${ }^{\text {g, F. Finaudi }}{ }^{\text {f,g }}$, L. Galli g,h, Y. Gao ${ }^{\mathrm{g}}$, J. Geldmacher ${ }^{\mathrm{g}}$, L.A. Gilbert ${ }^{g}$, N.W. Hayman ${ }^{\text {h}}$, E. Herrero-Bervera ${ }^{g}$, N. Hirano $^{\text {h, S. Holter }}{ }^{\mathrm{g}}$, S. Ingle ${ }^{\text {h }}$, S. Jiang ${ }^{\text {f }}$ U. Kalberkamp ${ }^{\text {f }}$, M.

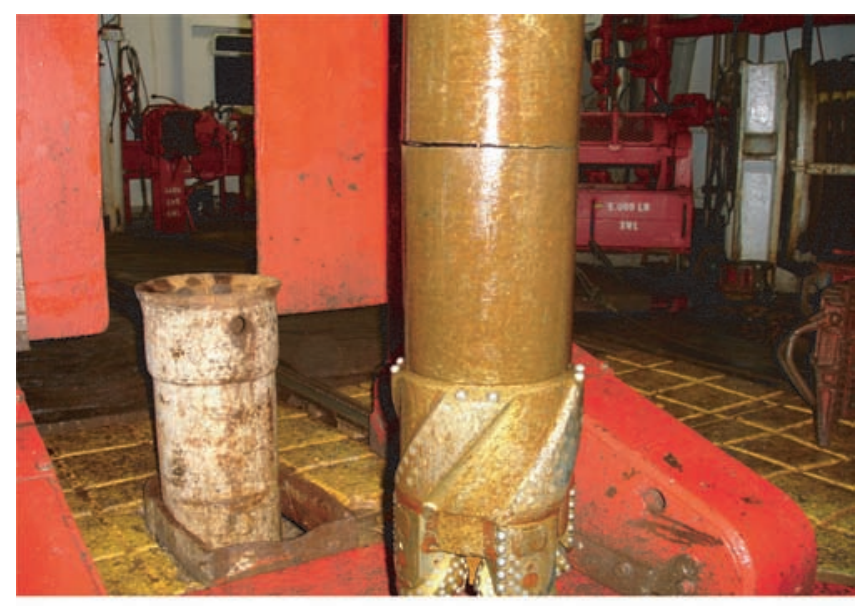

Figure 7. Torsional failure of the bit sub during Expedition 309. A horizontal gash opened for $\sim 150^{\circ}$ ( 11 inches) of the circumference of the $3 / 4$-inch thick bit sub wall, $\sim 15$ inches from the bit, with more ragged fracture tips propagating a further $\sim 75^{\circ}$ around the pipe from each end of the clean fracture. When in tension with the drill bit hanging from the sub, the fracture opened up to $1 \mathrm{~cm}$, and the bit was held on by only $\sim 4.25$ inches of the bit sub wall.
Kerneklian f, J. Koepke h, Ch. Laverne f,g,h, H.L. Lledo

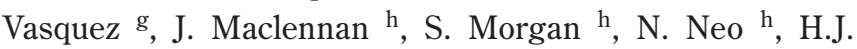

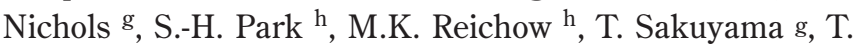
Sano g, R. Sandwell f, B. Scheibner ${ }^{h}$, Ch.E. Smith-Duque ${ }^{g}$, S.A. Swift h, P. Tartarotti f,g , A.A. Tikku h, M. Tominaga ${ }^{\text {g,h }}$, E.A. Veloso g,h, T. Yamasaki h, S. Yamazaki h, and $\mathrm{Ch}$. Ziegler ${ }^{\mathrm{f}}$.

${ }^{\mathrm{a}}$ Co-Chief Scientist Leg 206, ${ }^{\mathrm{b}} \mathrm{Co}$-Chief Scientist Expedition 312, c Staff Scientist Expedition 309 and 312, ${ }^{\mathrm{d}}$ Co-Chief Scientist Expedition 309, ${ }^{\text {e }}$ Staff Scientist Leg 206, ${ }^{\mathrm{f}}$ Leg 206 Scientific Party, ${ }^{\mathrm{g}}$ Expedition 309 Scientist, ${ }^{\mathrm{h}}$ Expedition 312 Scientist.

\section{References}

Alt, J.C., Laverne, C., Vanko, D.A., Tartarotti, P., Teagle, D.A.H., Bach, W., Zuleger, E., Erzinger, J., Honnorez, J., Pezard, P. A., Becker, K., Salisbury, M.H., and Wilkens, R.H., 1996. Hydrothermal alteration of a section of upper oceanic crust in the eastern equatorial Pacific: a synthesis of results from Site 504 (DSDP Legs 69, 70, and 83, and ODP Legs 111, 137, 140, and 148). In Alt, J.C., Kinoshita, H., Stokking, L.B., and Michael, P. (Eds.), Proc. ODP, Sci. Results: College Station, Texas (Ocean Drilling Program), pp. 417-434.

Bascom, W., 1961. A Hole in the Bottom of the Sea: The Story of the Mohole Project: New York (Doubleday and Company), $352 \mathrm{p}$.

Cande, S.C., and Kent, D.V., 1995. Revised calibration of the geomagnetic polarity timescale for the Late Cretaceous and Cenozoic. J. Geophys. Res., 100:6093-6095. doi:10.1029/94JB03098

Carbotte, S., Mutter, C., Mutter, J., and Ponce-Correa, G., 1997. Influence of magma supply and spreading rate on crustal magma bodies and emplacement of the extrusive layer: insights from the East Pacific Rise at lat. $16^{\circ} \mathrm{N}$. Geology, 26:455-458. doi: 10.1130/0091-7613(1998)026\%3C0455:IOM SAS\%3E2.3.CO;2

Expedition 309 Scientists, 2005. Superfast spreading rate crust 2: a complete in situ section of upper oceanic crust formed at a superfast spreading rate. IODP Prel. Rept., 309: doi:10.2204/ iodp.pr.309.2005.

Expedition 309/312 Scientists, 2006. Superfast spreading rate crust 2 and 3: a complete in situ section of upper oceanic crust formed at a superfast spreading rate. IODP Prel. Rept., 312: doi:10.2204/iodp.proc.309312.101.2006.

Greenberg, D.S., 1974. MoHole: geopolitical fiasco. In Gass, I.G., Smith, P.J., and Wilson, R.C.L. (Eds.), Understanding The Earth: Maidenhead, UK, (Open University Press) pp. 343-349.

Hallenborg, E., Harding, A.J., Kent, G.M., and Wilson, D.S., 2003. Seismic structure of $15 \mathrm{Ma}$ oceanic crust formed at an ultrafast spreading East Pacific Rise: evidence for kilometerscale fracturing from dipping reflectors. J. Geophys. Res., 108:2532. doi:10.1029/2003JB002400.

Ildefonse, B., Blackman, D., John, B.E., Ohara, Y., Miller, D.J., MacLeod, C.J., and IODP Expeditions 304-305 Scientific 
Party, 2006. IODP Expeditions $304 \& 305$ characterize the lithology, structure, and alteration of an oceanic core complex. Sci. Drill., 3:4-11, doi: 10.2204/iodp. sd.3.01.2006.

Karson, J.A., 2002. Geologic structure of the uppermost oceanic crust created at fast- to intermediate-rate spreading centers. Annu. Rev. Earth Planet. Sci., 30:347-384. doi: 10.1146/ annurev.earth.30.091201.141132.

Phipps Morgan, J., and Chen, Y.J., 1993. The genesis of oceanic crust: Magma injection, hydrothermal circulation, and crustal flow. J. Geophys. Res., 98: 6283-6297.

Teagle, D.A.H., Wilson, D.S., Acton, G.D., and ODP Leg 206 Shipboard Party, 2004. The "Road to the MoHole" four decades on: deep drilling at Site 1256. EOS, Trans. Am. Geophys. Union, 85:521,530-531.

Teagle, D.A.H., Alt, J.C., Umino, S., Miyashita, S., Banerjee, N.R., Wilson, D.S., and the Expedition 309/312 Scientists, 2006. Superfast Spreading Rate Crust 2 and 3. Proc. IODP, 309/312: Washington, DC) Integrated Ocean Drilling Program Management International, Inc., doi:10.2204/iodp. proc.309312.2006

Umino, S., Obata, S., and Lipman, P.W., 2000. Subaqueous lava flow lobes, observed on ROV KAIKO dives off Hawaii. Geology, 28:503-506, doi:10.1130/0091-7613(2000)28<503: SLFLOO $>2.0 . \mathrm{CO} ; 2$

Wilson, D.S., Teagle, D.A.H., Acton, G.D., and Firth, J.V., 2003. An in situ section of upper oceanic crust created by superfast seafloor spreading. Proc. ODP Init. Res., 206:1-125. Texas A\&M University, College Station, Texas (Ocean Drilling Program).

Wilson, D.S., Teagle, D.A.H., Alt, J.A., Banerjee, N.R., Umino, S., Miyashita, S., Acton, G.D., Anma, R., Barr, S.R., Belghoul, A., Carlut, J., Christie, D.M., Coggon, R.M., Cooper, K.M., Cordier, C., Crispini, L., Durand, S.R., Einaudi, F., Galli, L., Gao, Y., Geldmacher, J., Gilbert, L.A., Hayman, N.W., Herrero-Bervera, H., Hirano, N., Holter, S., Ingle, S., Jiang, S., Kalberkamp, U., Kerneklian, M., Koepke, J., Laverne, C., Lledo Vasquez, H.L., Maclennan, J., Morgan, S., Neo, N., Nichols, H.J., Park, S.-H., Reichow, M.K., Sakuyama, T., Sano, T., Sandwell, R., Scheibner, B., Smith-Duque, C.E., Swift, S.A., Tartarotti, P., Tikku, A.A., Tominaga, M., Veloso, E.A., Yamasaki, T., Yamazaki, S., and Ziegler, C., 2006. Drilling to gabbro in intact ocean crust. Science, 312:1016-1020. doi:10.1126/science. 1126090

\section{Authors}

Jeffrey C. Alt, Co-Chief Scientist Exp 312, Department of Geological Sciences, University of Michigan, 1000 North University, Ann Arbor, Mich. 48109-1005, U.S.A., e-mail: jalt@umich.edu

Damon A.H. Teagle, Co-Chief Scientist Exp 309, School of Ocean and Earth Science, National Oceanography Centre, University of Southampton, European Way, Southampton SO14-3ZH, U.K.

Susumu Umino, Co-Chief Scientist Exp 309, Department of Biology and Geosciences, Shizuoka University, Ohya 836, Shizuoka 422-8529, Japan.
Sumio Miyashita, Co-Chief Scientist Exp 312, Department of Geology, Niigata University, 8050 Ikarashi, Niigata 950-2181, Japan.

Neil R. Banerjee, Staff Scientist/Expedition Project Manager Exp 309 and 312, Dept. Earth Sciences, Univ. Western Ontario, London, ON N6A 5B7, Canada.

Douglas S. Wilson, Department of Earth Science and Marine Science Institute, University of California, Santa Barbara, Calif. 93106, U.S.A.

and the IODP Expeditions 309 and 312 Scientists and the ODP Leg 206 Scientific Party

\section{Related Web Links}

http://iodp.tamu.edu/publications/PR/312PR/312PR.html http://www-odp.tamu.edu/publications/206_IR/206ir.htm 